\title{
An Ideological Analysis of Counter-Elite Essentiality in On the Road *
}

\author{
Liu Xi, Wu Yi \\ Changchun University, Changchun, China
}

\begin{abstract}
Jack Kerouac (1922-1969) is regarded as the pioneer and spokesman of the Beat Generation, which emerged in the late 1940s and early 1950s. His masterpiece On the Road is honored as the bible of the Beat Generation. Since its publication, critical responses to the novel have polarized, from high praise to fierce denunciation, for the protagonists lead a wandering, unconstrained life, disobeying authority, and denying the values and moral standards of the elites so as to establish the counter-elite essentiality. The present paper aims to make an analysis of the counter-elite feature of the characters in the novel from three perspectives: (a) the introduction to Beat Generation and counter-elite essentiality; (b) their strong resistance against industrialized society; and (c) their fight against the ideology of elites.
\end{abstract}

Keywords: Beat Generation, elite, counter-elite, resistance

\section{Introduction}

Jack Kerouac (1922-1969), an American postmodern novelist and poet, is generally looked on as the father of Beat Movement. He is always regarded as an iconoclast and a pioneer of the Beat Generation in literary circle with other writers like William S. Burroughs and Allen Ginsberg. Many of his books exemplified the spontaneous approach, including On the Road which was written as a stream of consciousness, Visions of Cody, Visions of Gerard, Big Sur, and The Subterraneans. The central features of this writing method are the ideas of breath which is borrowed from Jazz and from Buddhist meditation breathing, improvising words over the inherent structures of mind and language, and not editing a single word. What is connected with his idea of breath is the elimination of the period, that is, the use of a long, connecting dash. As such, the phrases occurring between dashes resemble improvisational jazz licks. When spoken, the words take on a certain kind of rhythm, though none of it pre-meditated.

In April 1951, Kerouac wrote for three weeks on a continuous roll of paper and finished the first complete version of On the Road. When the book was finally published in 1957, Kerouac became an instant celebrity. Kerouac is best known as the father of the Beat Movement, and On the Road endures as his most significant work. The novel depicts a story of how several American young men sought for their American dreams and how their dreams disillusioned. The two main characters of the book are the narrator, Salvatore Paradise, and his new friend, Dean Moriarty. Dean admires for Salvatore's carefree attitude and sensation for adventure. He

\footnotetext{
* This paper is a part of the results of the research program "The Study of Counter-Elite Essentiality in American Post-modernism Novels" (2013, No.265) the authors have participated in.

Liu Xi, M.A., lecturer, School of Foreign Languages, Changchun University.

$\mathrm{Wu}$ Yi, M.A., associate professor, School of Foreign Languages, Changchun University.
} 
thinks Salvatore is like a free-spirited maverick eager to explore all kicks in his journey. The novel consists of five parts, three of them describe a road trip from New York to the West Coast, one to Mexico, and the last part is about their final encounter when Dean comes to visit Sal in New York. During their trips and adventures, they change a lot along with their relationship. The narrative is about what happened during the years from 1947 to 1950, and it is full of Americana which marks a specific era in jazz history. As for the form of the novel, it is inimitable because it reverses the rigor and the regularity in the structural narration. The plots thoroughly reflect the behaviors of the characters and the confusion in their ideology which reflects the cause of the disillusion of "American dreams."

The present paper aims to make an analysis of counter-elite essentiality of the ideology from the perspectives of strong resistance from Salvatore and Dean against industrialized United States (U.S.) and their fight against elites.

\section{Beat Generation and Counter-Elite Essentiality}

The Beat Generation was a group of American postwar writers who were prominent in the 1950s, as well as the cultural phenomena that they inspired. "The core group consisted of Jack Kerouac, Allen Ginsberg, Neal Cassady and William S. Burroughs, who met in the neighborhood surrounding Columbia University in uptown Manhattan in the mid-40s" (Schlueter, 1985, p. 65). They picked up Gregory Corso in Greenwich Village and found Herbert Huncke hanging around Times Square. They then migrated to San Francisco where they expanded their group consciousness by meeting Gary Snyder, Lawrence Ferlinghetti, Michael McClure, Philip Whalen, and Lew Welch. Most of them struggled for years to get published, and it was inspiring to learn how they managed to keep each other from giving up hope when it seemed their writings would never be understood. Their moment of fame began with a legendary poetry reading at the Six Gallery in San Francisco. Central elements of Beat Culture include a rejection of materialism, the idealizing of exuberant, unexpurgated means of expression, an interest in Eastern religion, and alternative forms of sexuality and even experimentation with drugs. These features are obviously against mainstream values prevailing in the U.S. in the 1950s. The Beat Generation consists of two waves which are still influential at present days.

The Beat Generation is a phenomenon regarded as a great and moving cluster of individuals who changed culture, literature, and history in their flight. Beat classes are becoming more popular in universities; online forums are devoted to discussions of the beats; beat-related books and products have their highest sales ever; and so on. The soul works are written to reveal the American cultural and political reforms with sincerity and amazing courage of thought. What Beat Generation left was some ideology or spiritual heritage related to man's culture beyond the American borders. From the mid-20th century, their way of life and spiritual pursuits in succession in Europe, Asia, and South America evoked a strong response around the world present days.

In the meanwhile, industrial growth transformed American society. It "produced a new class of wealthy industrialists, a prosperous middle class and elites" (Yu, 2002, p. 76). Because the U.S. industrialization was made possible by the labor force, American society turned on a more diverse look than ever before. But while increased production did boost living standard of American people, industrialization concentrated on great wealth and power in the hands of a few industrial magnates. Because economic growth increasingly much influenced all aspects of American society, then, it created both new opportunities and new social problems.

What were new social problems prevailing in industrialized U.S.? "The process of industrial civilization converted America into an organized world" (Yu, 2002, p. 119). That is to say, the national administration was 
so involved in the freezing state that it lost its energy because governmental administration were largely dominated by power elites who merely had artificial wants, monotony, and narrow mechanical understanding. In this sense, there was the occurrence of the counter-culture movement in the 1960s among American new youth and student subcultures and particularly the hippies. Thus, undoubtedly, there was an intimate relation between Beat Generation and counter-elites. "Counter-culturalists valued the spiritual over the material, hedonism over prudence, tolerance over prejudice” (Zott, 2003, p. 17).

In On the road, the two main characters, Salvatore Paradise and Dean Moriarty, were not exceptional to express their resentment and resistance to contemporary U.S. society because they never concealed the anxiety over the organized nation characterized by great uniformity in which hierarchies of authority and monotonous regulations were prevailing so that traveling was obviously symbolized as the weapon to fight against the stereotyped world, the industrialized U.S. society.

\section{Strong Resistance Against Industrialized American Society}

In the novel On the Road, the author Kerouac presents Salvatore Paradise, a young and innocent writer, and Dean Moriarty, a crazy young man tremendously excited with life to race around America, and testing the limits of the American dream. Their journeys consist of scenes of rural wilderness, sleepy small towns, urban jungles, and endless deserts, which were all linked by the road, the outlet of a generation's desire and inner need to get out, to break its confinement, and to find freedom so that they would liberate themselves from any higher belief, notion, or ideology to show their counter-elite values. The desperation and the lack of fulfillment made these youths feel that "The only thing to do was go" (Kerouac, 2000, p. 38), searching for their personal freedom, and finding pleasure in sex, drugs, and jazz.

In the novel, Salvatore and Dean considered jazz as a way to express their standpoint and passions rather than a tool to extol the aggressive industrialized U.S.. Actually, jazz was symbolized as a fundamental element in the Beat subculture. Jazz musicians were heroes and sages to them. In New Orleans, they continued their immersion in drugs and music. As for this point, they were at the very height of the Beat ideal, crossing the country and stopping to meet fascinating people with whom they could share counter-elite values. They viewed themselves as a peculiar kind of male animals who became obsolete in a man's world with increasing amounts of organizations characterized by the inanimate governmental administrations and formalistic traditions and conventions. From this perspective, their hot pursuit of jazz not only showed their strong resistance against traditional mainstream values, but also demonstrated their counter-elite essentiality in their ideology.

Later, Dean used up all his savings to buy a car in order to satisfy his desire to move around the continent regardless of his starving wife and daughter. As for them, journey carried much significance because it was a way to express their unique counter-elite value, that is, a strong desire to acquire a real independence and freedom far from machined industrial civilization in the U.S.. Thus, they moved back and forth, from east to west, and from civilized areas to primitive places. On the road, they were pursuing individual freedom and independence all the time.

Jack Micheline, a poet who was associated with the Beat Movement, once said:

The Beat Generation is a way of life. All my life I have been rebelling against something or other. The reason for my rebellion is that I want to be able to be what I want, do what I want, without being restricted. I fight to remain myself. (Schlueter, 1985, p. 186) 
The protagonists in the novel tried their utmost to quest for their identity and internalize their counter-elite essentiality by intermingling with people on the margins. However, no matter how rough the "road" was, they never shook off the ambition which exerted too much influence on them. They desperately attempted to reject the conventional mainstream values on one hand, while on the other hand, they turned to the "square" people of the mainstream as soon as they stuck in trouble or got bored of wandering along the road. They two set off on their journey in the hope of converting their counter-elite belief into others. They disdained the traditional norms valued highly by the dominant society. Although their rebellion was not a violent or political one, it was a rebellion of ideology, so that it aroused people's awareness of the deficiency of existing mainstream values, and thus, had a profound influence on American culture.

The novel shows the reflections of the two main characters to explore and pursue different forms of deep-rooted spirit. The Beats writers are most in-depth, the most persistent and comprehensive exploration into the post-war excitement seeking immoderation, trying to break freedom so that they asked to express their own aspirations of young men in the eyes of the classic. From Kerouac's novel, we can see the post-war American youth's anxiety, confusion, and their pursuit and exploration which reflected in the history of the Beats Movement, and expressed the aspirations of the era of American youth and opened the new counter-elite ideology in American culture and literary history.

\section{Fights Against Ideology of Elites}

In the story, Salvatore Paradise and Dean Moriarty were always on the road. "From New York to Denver, from Denver to San Francisco, to New York..." (Kerouac, 2000, p. 25). Continuous travel made them get to know each other and come across totally strange people with whom share their stories. "We think it would be a mundane life, but it continues to appear the fate but chance" (Kerouac, 2000, p. 31). In the novel, the two main characters kept shuttling among the highways and the cities. They traveled on the road with loneliness, depression, happiness, and numbness to New York, Denver, San Francisco.... Whenever arriving at some city, they always found that the dream was still in the distance, they could only continue to move forward towards it.

In the 1950s, America was approaching postindustrial epoch. "The postindustrial society was brought about by a shift of the labor force from agriculture to industry, then from industry to services, followed, in the view of its first modern advocate by the emergence of a new knowledge society" (Schlueter, 1985, p. 85). The elites were declining while the power of the masses was incredibly growing, since the process of industrial civilization resulted in prevailing depression in people's mind, especially those who belonged to the higher circles and middle classes, including the elites. However, the spiritual depression made elites bewildered about their life aims while they wallowed in obeying the orders like machines aimlessly as if they were suddenly bankrupt in the life targets.

Superficially speaking, their wandering on the road carried no significance. They loved the natural landscapes in the highways and cities rather than the artificial beauty created by industrialized American elites. They have no destination for their trip, and they thought that someday they had lost their American dreams, so that they had to restart to seek for their future and belief. However, unconsciously looking for something in this trip, at first, they traveled aimlessly for what they want. In fact, it was unlikely to say that there was any direction for their journey, they only needed to go forward and never stayed in a place. Later, they became more mature in their ideology because they came to understand the purpose of their journey after a long-time spiritual confusion. In this sense, we may say, the journey was a spiritual meditation and pursuit which made 
them understand their dreams better. In the past, they were attracted by artificial beauty in the man-made cities like others. They once thought American elites had established standard values for the whole society. Then, they entirely accepted such narrow and hidebound thoughts before they were greatly influenced by the ideology of Beat Generation.

To some extent, On the Road is a spiritual pursuit of the two counter-elites. Salvatore Paradise asked, “... Your road, man? ... the way of the good boy, crazy way, a colorful way, dandy way, any way in the end where to what, how to go?" (Kerouac, 2000, p. 178). Each time when they packed up to travel on the road to explore the unpredictable journey, it seemed that they were capable enough to control the mysterious possibilities and colorful outside world. What is more, it can be viewed as unparalleled temptation to attract millions of people, especially young people on the road. At present days, "the road" has become a pursuit of freedom which carries a universal significance. On the Road is more like a ritual of an unlimited future to explore and an awareness of self-worth so as to establish their counter-elite essentiality.

\section{Conclusion}

This novel depicts the eastern U.S. Beat molecular and it is regarded as a "living textbook" as well. On the Road typically reflects the improvisation of itself. On the Road has brought a great influence on the writers in the literary circle, including Bob Dylan, Van Morrison, Jim Morrison, and many more writers. At least two great American photographers were influenced by Kerouac: Robert Frank, who became his close friend-Kerouac wrote the introduction to Franks' book, The Americans-and Stephen Shore, who set out on an American road trip in the 1970s with Kerouac's book as a guide. Many critics realize the social meaning of the book and accept it as one of the major contributing factors leading to the social unrest of the 1960s. The novel actually advocates its counter-elite essentiality with the characterization of Salvatore Paradise and Dean Moriarty who revealed their counter-elite ideology by the resistance against industrialized American society and fight against the elites. The success of the novel is still a mystery among the literary circle.

\section{References}

Bennett, T. (2005). New keywords: A revised vocabulary of culture and society. Oxford, U.K.: Blackwell Publishing Ltd.. Elliott, E. (1988). Columbia literary history of the United States. New York, N.Y.: Columbia University Press.

Frow, J. (1995). Cultural studies and cultural value. Oxford, U.K.: Oxford University Press.

Gilbert, M. (1957, September 5). Review of On the Road. New York Times, p. 27.

Kerouac, J. (2000). On the road. New York, N.Y.: Penguin Books.

Payne, M. (1996). A dictionary of cultural and critical theory. Oxford, U.K.: Blackwell Publishers Ltd..

Schlueter, P. (1985). Modern American literature. New York, N.Y.: Frederick Ungar Publishing Co..

Yu, W. X. (2002). Cultural study: An introduction. Beijing: People Press.

Zott, L. M. (2003). The Beat Generation: A gale critical companion. Detroit: Gale. 